announcer in the broadcasting service with the excessive modulation of his Swedish confrère; or the stolid utterance of the Somerset man with the lilt of the East Anglian or Northumbrian. This is a characteristic which may readily be measured on inexpensive electrical apparatus of the noise meter and beat-frequency types. Both these instruments incorporate some form of valvevoltmeter in their final stages, the deviations of which from a mean setting (of intensity and frequency, respectively) can be recorded as a flickering of the needle, or, better still, as the root mean square value of the deviations. The latter figures can be obtained if some form of wattmeter in the output stage is used, and may be taken as a measure of intonation, in the same way that the root mean square value of the deviation from a standard stream velocity is taken in hydrodynamics as a measure of the intensity of turbulence in the stream.

Nor must the physiologist be left out of this work. Though experiments on the vocal apparatus of dead mammals played a part in the early development of phonetios as an experimental science, results so obtained are rather discounted as criteria for the science of the human voice to-day. Much, however, is to be learnt from X-ray photographs of the larynx taken when set in position for the production of a sound, which is oscillographed at the same instant. Such studies are being made by-among others-- Prof. 0 . Russell in America and Dr. R, Curry in England.

Other work which should prove of great import to linguistic studies involves the taking of highspeed cinematograph pictures of the motion of the vocal cords as seen through the laryngoscope. Such photographs, in various modes of action of the cords, normal, falsetto, etc., are now being obtained in the laboratories of the Bell Telephone Company at New York.

${ }^{1}$ NATURE, 133, 655 (1934).

\title{
PLANNED WHEAT PRODUCTION
}

\section{By Sir John Russell, F.R.S., \\ Rothamsted ExpERIMENTAL Station}

$\mathrm{W}^{\mathrm{n}}$ Save in Great Britain nothing quite like the Food Research Institute of Stanford University, California, which periodically publishes important monographs on foods, and in consequence it would have been difficult to produce here the comprehensive study "Competition among Grains" recently issued by Dr. Jasny. Mr. Paul de Hevesy's achievement in completing his great work "World Wheat Planning* is therefore all the more remarkable, and he is to be congratulated on having brought together in one volume an enormous mass of data relating to the production of wheat in the different countries of the world, its distribution and its consumption. The labour involved has been prodigious, but it is known that he has been engaged on this work for a long time, and his extensive knowledge of the subject is well recognized.

Wheat, like sugar, affords an example of the triumph of politics over Nature. Both crops grow admirably in the regions naturally suited to them, and these regions are adequate to produce all, and more than all, that the world is likely to require. If they were in fact called on to produce all the supplies, the necessary corollary would be un-

* World Wheat Planning and Economic Planning in General. By Paul de Hevesy. Pp. xv+912. (London: Oxford University Press, 1940.) 388. net. hampered trade between the producing and the consuming countries. But there is an alternative method. Science has opened up the possibility of growing both crops in conditions not naturally suited to them, and so enabled many countries to produce their own supplies. It is true that the supplies cost more, are less certain and less abundant than by the other method, but in those countries where political considerations have dictated a policy of autarky or self-sufficiency, agricultural science is called upon to make the best of the task of growing a crop in conditions not really suited to it. Two general methods are adopted: the environmental conditions are changed by various devices of soil management, and the plant is changed by cross-breeding and other methods. Sooner or later pathological problems arise, sometimes of great importance : these also have to be dealt with.

Wheat is really a plant of the semi-arid regions : it has been found wild in Asia Minor, northern India, Abyssinia, etc. Throughout long years of cultivation many varieties have been selected or bred, but the crop still retains its semi-arid nature.

The optimum climatic conditions for wheat production are a moderately low rainfall of about 20-25 inches per annum, with dry warm weather 
for maturation and harvesting. These conditions prevail over great belts of continental areas, especially in North America, Australia, and Eastern and Central Europe, including the U.S.S.R.; in these regions wheat can be grown cheaply and in abundance. England, with its many soils and climates, also has a considerable proportion of wheat-growing regions. The area east of a line from Durham to the Isle of Wight is largely suitable; and another area extends westwards from the southern part of this line; the boundary is roughly the escarpment formed by the Inferior Oolite outcrop. The determining factor is chiefly the rainfall but with soil as a strong subsidiary, for wheat is less easy to grow than grass on a heavy clay soil or than barley on a light one, so that it tends to keep to the loams. It is better suited to heavy than to light soils, and in the old days was much grown on the clays in the eastern counties, the Midlands and the south; for this purpose the land was laid up in high ridges separated by deep furrows, many of which still remain, giving a curious wave-like appearance to the pastures. Their original purpose was to provide drainage, and although modern mole-draining would be much better, the cost of levelling the ground would be more than the land was worth.

The area under wheat in Great Britain was at a maximum in the early 1870 's, when there were $3 \frac{1}{2}$ million acres. The total production was probably about $2 \frac{1}{2}$ million tons, sufficient for the needs of 19 million people at present rates of consumption (300 lb. wheat per head per annum). The population of Great Britain in 1871 was 26 millions, so that the home production amounted to 73 per cent of the total consumption.

Even in those days there were importations of wheat from America, Australia and Europe, but only by way of completing the home supplies. Then, with almost dramatic suddenness, wheat growing in England become unprofitable. The American and Canadian farmers had been rapidly breaking up the prairies, the railway was pushed across the continent and the trans-Atlantic steamship services were organized. When the chain was completed, wheat was brought over from North America in great quantities and sold on our markets at prices far below the cost of production here and, in some years during the financial crises in the West, below the cost of production there. The politicians of the day decided to leave economic forces alone and so did nothing; English farmers gave up wheat.growing, and a short time before the War we were producing not much more than 10 per cent of our total consumption. Then the Government stepped in, and virtually made a contract with farmers to produce about 15 per cent of home requirements at an agreed price.
The actual arrangements were complicated by the fact that the Government did not wish to interfere with the usual marketing arrangements, and so left the ordinary machinery at work, but paid to the farmers the difference between the market price which they had actually received and the contract price which they were due to receive. These are called 'deficiency payments' ; they work well enough so far as the farmer is concerned. Unfortunately a section of the Press calls it a "subsidy", which, of course, it is not. Most business enterprises nowadays are worked on contracts, and it would be a very good thing if the system were more widely extended to agriculture.

As a result of the Wheat Quota Act, the nation can count on 15 per cent of its requirements being met at home, and in peace-time this proportion is fairly satisfactory, though a case could be made for a larger one; however, the figure is a good compromise. For there is a very considerable difference between ordinary English and imported wheat: the English wheat does not give the large, well-piled loaf obtainable with the so-called 'strong' imported wheat, and the English housewife, therefore, does not like it and will not buy it. Most of the mills are situated at the ports, and they use in normal times only a small fraction of English wheat: the inland mills use more, especially when they can get the one 'strong' wheat commonly grown in England-Yeoman, produced by Sir Rowland Biffen at Cambridge. English wheat is much used for biscuit-making and for poultry feeding; for both purposes it is admirable. What English wheat lacks in 'strength', however, it more than makes up in power of growth, and the English 'weak' wheats include some of the heaviest yielders known. 'Strength' refers only to the character of the dough, and has nothing to do with vigour of growth of the plant or nutritive value of the grain.

In war conditions, a production of only 15 per cent at home is insufficient, and efforts are therefore made to increase the output here. The chief difficulty is that wheat is one of the less productive crops: it usually gives less than 1 ton per acre of dry matter for human food, while potatoes yield two to three tons of dry matter and mangolds may give double this quantity-this, however, is food for animals. The war-time increase comes from the ploughing up of the less productive grass land, our great national reserve of fertility.

An important reason for relying on importation in peace-time is that wheat is one of the easiest of all crops for the farmers on great continental plains to grow. Their first methods led to severe soil erosion, but where this has not gone too far the modern methods are free from this objection. Wheat is also one of the easiest of all agricultural 
products to store, to transport, and to sell. In a world permanently at peace, densely populated countries like Great Britain could confine themselves to crops giving larger quantities of dry matter per acre, or to products like vegetables, milk, eggs; high-quality meat and fruit where freshness is an asset.

A cynic looking for examples of human folly could find none better than the human treatment of the bountiful supplies of wheat of the last fifteen years. The nations pray that their daily bread may be given to them, and it has been, with a margin to spare. Mr. Hevesy gives a completely dispassionate and objective statement of the results. During the period 1926-34, the world produced more wheat than it consumed : the margin was only small, and never exceeded 2.5 per cent except in one year, but the continued small overproduction made the markets so sensitive that prices fell to ruinous levels. Since most of the world's population is engaged in agriculture this loss of purchasing power by farmers and farm workers led to serious industrial and financial depression. The over-production did not arise from heavy yields, but from an extension of acreage partly in Europe as a consequence of the selfsufficiency policy.

Countries that lived in part on their wheat exports-Canada, Australia, the Argentine-had to subsidize their farmers to save them from bankruptcy, while countries that aimed at selfsufficiency found themselves obliged to export temporary surpluses at shipwreck prices, paying the normal price, however, to their producers. Mr. de Hevesy instances a country where 25 million quintals (92 million bushels) excess were produced at an average cost of 19 gold francs (that is, the Swiss franc before its devaluation in September 1936) per quintal which had to be exported at 6-7 francs, the difference being made up by the taxpayer. Yet the small percentage excess that was causing all the trouble was not really superfluous : millions of people in Europe and other countries were under-nourished, but the attempts made at Geneva and elsewhere to persuade nations to buy more bread-and-butter failed.

The trouble was intensified by fiscal arrangements. An inquiry showed that during 1929-30 consumers paid 66,000 million gold franes for their bread, but the growers received only 36 per cent of this total; most of the remaining 64 per cent went in taxes.

There were considerable indications of a further wheat crisis ahead had not the War brought on a still greater crisis. The "Big Four"-the United States, Canada, Argentine and Australiawere last August discussing the possibility of arranging for quotas, and after agreement they intended to hold a wheat conference in London to be attended by the U.S.S.R. and the Danubian countries. The War stopped this, but Mr. Hevesy thinks more wheat crises, with all their attendant evils, are inevitable until world wheat production is planned and organized.

Much of the book is occupied with a full description of wheat production in all countries from. which any information can be obtained. In a particularly interesting section on Germany it is pointed out that, prior to the War, Germany was one of the foremost wheat-importing countries, but during the period 1931-35 she became nearly self-sufficient and can now, if the harvest is good, produce all her requirements of wheat, rye and other grains. Nevertheless Germany bought some $15 \frac{1}{2}$ million bushels of wheat from wheat-exporting countries during the autumn of 1938, and her reserves must now be considerable. The yield of wheat in Germany between 1890 and 1930 increased by about 11 bushels per acre and is now about 32-33 bushels per acre, about as much as our own yield. Gigantic distributing machinery has been set up called Reichsnährstand, a kind of cartel including all farmers and their associations, all merchants of agricultural produce, the exchanges and all processing industries. It is organized like the National Socialist Party itself, having in the village its "confidential agents", above these the district leaders, and at the top the chief for the whole Reich ; practically all the officials are members of the Party. It exercises very complete control over farmers, salesmen, millers and all others who handle food production. The farming is based on the Hereditary Farm Law of 1933, setting up about 700,000 hereditary farms which may be inherited by one child only, usually the eldest, who has no power to subdivide, sell, or mortgage the land without a State permit, and if this is granted at all it is only for sale to another farmer.

While the fixing of prices is effectively carried out, there is no such planning of production as in the U.S.S.R. ; it is left to the individual to decide what he shall sow, and this seems to be all that is at his discretion. The Government, of course, influences his decision by the prices they fix. In the end food prices are considerably higher than in England and the standard of living of the people is lower.

In the section on the U.S.S.R., Mr. Hevesy finds no evidence of increased yields since the pre-Revolution days, notwithstanding enthusiastic claims as to what Russian science has done for agriculture; also he states that the cost of production, so far as can be ascertained, is very high, in spite of the much-praised mechanization and social-economic system. The total production of 
wheat seems not to have kept pace with the growth of population. However, Russian wheat statistics are complicated by the change which took place in 1933; prior to that date they were based on the grain actually collected; after that date they are based on the "biological" or unharvested crop, a deduction being made for "technically inevitable losses in harvesting". In 1933 the deduction was given as 10 per cent, that is, about I bushel per acre, but much doubt has been expressed as to whether the losses could be kept as low ; the figures for production are taken by Dr. Schiller as maximum figures which certainly have not been exceeded.

\title{
THE HYDROGEN BOND
}

\author{
BY DR. C. E. H. BAwn, \\ UNIVERSITY OF BRISTOL
}

$I^{\mathrm{T}}$ has been recognized for many years that under certain conditions a hydrogen atom can form a connecting link between two other atoms. It may be considered as forming a bond between them, known as the hydrogen bond. Although the hydrogen bond is not strong, recent investigations have shown it to be of very wide occurrence. The concept has been extremely useful in explaining the association of polar liquids like water, the association of carboxylic acids, alcohols, amides, etc., the closure of rings within the molecule, and in interpreting many measurements of structure by X-ray and electron diffraction methods and of the frequency shifts of the infra-red absorption bands of certain known groupings. It was investigations of this type that not only established the existence of this form of bond but also provided information regarding the conditions in which its formation is to be expected, and, in many cases, of the actual energy of the bond. In spite of the enormous amount of experimental data now available, there is still much information which is lacking; the exact mechanism of the bonding power of the hydrogen is not clear, and there are many difficulties with questions of terminology.

With the object of clarifying the situation, a general discussion on "The Hydrogen Bond" was held by the Faraday Society on May 17 at the Imperial College of Science and Technology, London. A number of subjects was discussed in the six papers presented to the meeting, but briefly, the discussion can be considered under two headings: (1) the methods of studying hydrogen bonds by infra-red absorption, X-ray diffraction, and magnetic susceptibility measurements, and a survey of the results obtained; and (2) the occurrence of hydrogen bonds in molecules of biological importance, such as the proteins and carbohydrates.

It follows from the quantum-mechanical theories of valency that hydrogen cannot form more than one covalent bond and that the attraction of two atoms as found in hydrogen bond formation must be due to ionic forces. The positive hydrogen ion with no electronic shell around it attracts one anion to its normal internuclear separation, and this could then attract a second anion, namely, $X^{-} \mathrm{H}^{+} Y^{-}$. As might be expected, the strength of the bond formed should increase with increase in the effective negative charge of the bonded atoms. Thus fluorine, oxygen, nitrogen, and chlorine should form hydrogen bonds of strength decreasing in this order. Perhaps the best example of this type of ionic bonding is the $\mathrm{HF}_{2}-$ ion; Pauling considers that this ion resonates among three structures :

$$
\begin{aligned}
& \mathrm{F} \quad \mathrm{H} \quad \mathrm{F}- \\
& \mathrm{F}-\mathrm{H}+\mathrm{F}- \\
& \mathrm{F}-\mathrm{H} \quad \mathrm{F}
\end{aligned}
$$

When we come to consider more complex structures involving intermolecular hydrogen bonds, steric requirements must also be satisfied, that is, the interacting groups must be capable of sufficiently close approach to enable the attractive forces to come into play. When we review the conditions of formation of the hydrogen bond, it is not at all surprising that one meets examples of bonds covering a wide range of interaction, from strong bonds to weak bonds, finally emerging into groups of interaction which we know as due to van der Waals forces. It seems at present that the only means of characterizing the hydrogen bond in the molecule is the energy required to break it.

The most important and useful method for the discovery of hydrogen bonding is infra-red spectroscopy. The main results obtained up to the present time were discussed by Dr. G. B. B. M. Sutherland. Every molecule containing an $\mathrm{XH}$ group gives rise to well-marked absorption bands in the near infra-red, which are characteristic of the stretching and contraction of the $\mathrm{XH}$ bond. 